\title{
4. EU economic governance: a tool to promote or threaten social rights? The example of the right to collective bargaining
}

\section{Pieter Pecinovsky}

\section{INTRODUCTION}

With the financial and economic crisis which started in 2007 behind us, the EU found a new impetus to develop and reinforce its social dimension. The previous crisis led to the emergence of economic governance as an important policy mechanism for the EU. However, this so-called EU economic governance system also led to some questionable EU recommendations and national measures in the field of social policy and employment. This chapter provides a short overview of the EU economic governance system and explains, using the example of Spain, how the system has caused restrictions to social rights and the right to collective bargaining in particular - during the crisis. It shows how the situation improved during the Juncker Commission and how the von der Leyen Commission is promising to use EU economic governance to further implement the European Pillar of Social Rights and to support the development of social dialogue where necessary. Finally, this contribution looks at the current coronavirus crisis, which presents both a new threat to the social dimension of the EU and an opportunity for the EU and the Member States to prove that they have truly learned from past mistakes.

\section{EU ECONOMIC GOVERNANCE}

The EU uses economic governance as a system to monitor Member States' policies in the context of the Union's budgetary rules and its growth strategy 
(now: Europe 20201). The current system of EU economic governance is based on the development of Economic and Monetary Union, starting with the Stability and Growth Pact in $1997^{2}$ and gradually gaining a broader application with the Lisbon Strategy in 2000, the introduction of the European Semester in 2010 and the Europe 2020 Strategy. Two main forms of economic governance can be distinguished. ${ }^{3}$ First is the standard EU economic governance which is framed in the European Semester and culminates in the annual country-specific recommendations (CSR). These are supposed to be soft law guidelines for the Member States but they also contain characteristics of hard law; for instance, the budgetary recommendations related to the Stability and Growth Pact and those related to the Economic Imbalance Procedure are provided with sanctions. ${ }^{4}$ Second, there is a governance system, which could be called 'extreme EU economic governance', applied to countries in need of financial assistance from the other Member States (as seen in the cases of Greece, Portugal, Ireland, and so on). This system is part of the European

1 European Commission, Europe 2020: Europe 2020: A strategy for smart, sustainable and inclusive growth COM(2010) 2020 final; European Council, Conclusions of 25 and 26 March 2010, Brussels, EUCO 7/10; European Council, Conclusions of 17 June 2010, EUCO 13/10; Kenneth A. Armstrong, 'EU Social Policy and the Governance Architecture of Europe 2020' (2012) 18(3) Transfer 286; Susana Borrás and Claudio M. Radelli, 'The Politics of Governance Architectures: Creation, Change and Effects of the EU Lisbon Strategy' (2011) 18(4) Journal of European Public Policy 463, 465; Frank Hendrickx and Pieter Pecinovsky, 'EU Economic Governance and Labour Rights: Diversity and Coherence in the EU, the Council of Europe and ILO Instruments' in Axel Marx, Jan Wouters, Glenn Rayp and Laura Beke (eds), Global Governance of Labour Rights (Edward Elgar Publishing 2015) 120-1; J. Timo Weishaupt and Katja Lack, 'The European Employment Strategy: Assessing the Status Quo’ (2011) 7(1) German Policy Studies 9, 24-5.

2 Marco Buti, Daniele Franco and Hedwig Ongena, 'Fiscal Discipline and Flexibility in the EMU: The Implementation of the Stability and Growth Pact' (1998) 14(3) Oxford Revue of Economic Policy 81.

3 Pieter Pecinovsky, EU economic governance en het recht op collectief onderhandelen (die Keure 2019) 99-155.

$4 \quad$ Sonja Bekker, 'Hardening and Softening of Country-specific Recommendations in the European Semester' (2020) 44(1) West European Politics 114; Sonja Bekker and Saskia Klosse, 'EU Governance of Economic and Social Policies: Chances and Challenges for Social Europe' (2013) 2 European Journal of Social Law 103, 103-8; Sonja Bekker, 'EU Coordination of Welfare States after the Crisis: Further Interconnecting Soft and Hard Law' (2014) 19(3) International Review of Public Administration 296, 297-8; Simon Deakin, 'Social Policy, Economic Governance and EMU: Alternatives to Austerity' in Niklas Bruun, Klaus Lörcher and Isabelle Schömann (eds), The Economic and Financial Crisis and Collective Labour Law in Europe (Hart Publishing 2014) 95-6; Roland Erne, 'A Supranational Regime that Nationalizes Social Conflict: Explaining European Trade Unions' Difficulties in Politicizing European Economic Governance' (2015) 56(3) Labor History 345, 346. 
Stability Mechanism (ESM) and, for the time being, is outside the EU legal order, although it is closely linked to the EU. ${ }^{5}$ It qualifies as a hard law system, considering that non-compliance with the conditions of the ESM, as enforced by the Troika, may result in the bankruptcy of a country. ${ }^{6}$

\section{TENSION BETWEEN EU ECONOMIC GOVERNANCE AND SOCIAL RIGHTS}

\subsection{The Right to Collective Bargaining as One of the Main Targets}

An initial overview of all CSRs from 2011 onwards and the economic adjustment programmes of the Member States in need of financial assistance reveals that the EU (and the Troika) often gave recommendations in relation to the right to collective bargaining, but also pensions, the dismissal law, minimum wages, working time, and others. One of the most obvious tensions between EU economic governance and social rights has been the negative consequences for the fundamental social right of collective bargaining. Below, we shed light on this specific tension.

In earlier research, the author has analysed the EU recommendations for several Member States (Belgium, France, the Netherlands, Sweden, Italy, Spain, Portugal and Greece) with regard to collective bargaining. ${ }^{7}$ These recommendations were often related to national wage setting, on the one hand, and forced decentralisation, on the other. In some Member States, such as Belgium, the social partners play a crucial role in setting wages or the wage norm (the maximum wage increase). ${ }^{8}$ The EU found that wages in many Member States were too high and that the wage-setting system through which

\footnotetext{
5 Treaty Establishing the European Stability Mechanism, signed on 2 February 2012; Chistrophe Degryse, 'The New European Governance' (2012) ETUI Working Paper, 50; Hendrickx and Pecinovsky (n 1) 126; Isabelle Schömann, 'Changes in the General European Legal Framework' and Bruno Veneziani, 'Austerity Measures, Democracy and Social Policy in the EU' in Niklas Bruun, Klaus Lörcher and Isabelle Schömann (eds), The Economic and Financial Crisis and Collective Labour Law in Europe (Hart Publishing 2014) respectively 14 and 127.

6 Eleni Balamoti, 'Evaluating the New Rules of EU Economic Governance in Times of Crisis' (2014) European Labour Law Journal 95, 107; Simon Deakin, 'From Constraining to Rebalancing: The Role of Transnational Social Rights in Shaping European Union Economic Policy' in Wolfgang Däubler and Reingard Zimmer (eds), Arbeitsvölkerrecht (Nomos Verlagsgesellschaft 2013).

7 Pecinovsky (n 3) 323-443.

8 On the role of social partners see Filip Dorssemont, ch 3 in this volume.
} 
the social partners set wages did not function properly. ${ }^{9}$ Member States were subsequently urged to intervene in the collective bargaining process or to curb the process in order to limit an increase in wages. This is problematic in light of the principle of the autonomy of the social partners and free collective bargaining. With those interventions, the social partners' freedom to discuss and negotiate the content of collective bargaining agreements was restricted by the government. In addition, the EU made recommendations for decentralisation, with the aim of ensuring that collective bargaining on wages or other working conditions would not be set at national or sectoral level, but at company level. This is precarious, as trade unions are often less well represented - if at all - at company level, or are represented more weakly than at sectoral or national level, which can lead to employers unilaterally imposing certain measures without joint decision in collective negotiations. ${ }^{10}$ Naturally, unequal representation and negotiation power between the social partners is not conducive to voluntary collective bargaining. It should, in principle, be up to the social partners to choose the desired level of negotiation.

9 Guy Van Gyes and Thorsten Schulten, 'Introduction' in Guy Van Gyes and Thorsten Schulten (eds), Wage Bargaining under the New European Economic Governance: Alternative Strategies for Inclusive Growth (ETUI 2015) 11.

10 Gerhard Bosch, 'Shrinking Collective Bargaining Coverage, Increasing Income Inequality: a Comparison of Five EU Countries' (2015) 154(1) International Labour Review 57; Christian M. Dahl, Daniel le Maire, Jakob R. Munch, 'Wage Dispersion and Decentralization of Wage Bargaining' (2011) IZA Discussion Paper No. 6176, 38; Noélie Delahaie, Sem Vandekerckhove and Catherine Vincent, 'Wages and Collective Bargaining Systems in Europe During the Crisis' in Guy Van Gyes and Thorsten Schulten (eds), Wage Bargaining under the New European Economic Governance: Alternative Strategies for Inclusive Growth (ETUI 2015) 61-2; Antoine Jacobs, 'Decentralisation of Labour Law Standard Setting and the Financial Crisis' in Niklas Bruun, Klaus Lörcher and Isabelle Schömann, The Economic and Financial Crisis and Collective Labour Law in Europe (Hart Publishing 2014); Harry C. Katz, 'The Decentralization of Collective Bargaining: a Literature Review and Comparative Analysis' (1993) 47(1) ILR Review 3; Maarten Keune, 'Decentralizing Wage Setting in Times of Crisis? The Regulation and Use of Wage-related Derogation Clauses in Seven European Countries' (2011) 2(1) European Labour Law Journal 86; Paul Marginson, 'Coordinated Bargaining in Europe: From Incremental Corrosion to Frontal Assault?' (2015) 21(2) European Journal of Industrial Relations 97; Paul Marginson, Maarten Keune and Dorothee Bohle, 'Negotiating the Effects of Uncertainty? The Governance Capacity of Collective Bargaining under Pressure' (2014) 20(1) Transfer 37, 39-40; Florian Rödl and Raphaël Callsen, Collective Social Rights under the Strain of Monetary Union. Can Article 28 of the EU Charter of Fundamental Rights Offer Protection? (ETUI 2017) 97-8; Franz Traxler, 'Bargaining (De)centralization, Macroeconomic Performance and Control over the Employment Relationship' (2003) 23(1) British Journal of Industrial Relations 1, 2-8. 
Below, challenges to and examples of restrictions of the right to collective bargaining will be discussed with respect to the EU Member States in question. In some of these states the reforms, as a result of economic governance, have led to clear confrontations between the EU and other legal orders which play an important role for social rights, such as the Council of Europe and its European Social Charter (ESC) and the International Labour Organisation (ILO). In Spain and Greece, the collective bargaining reforms were condemned by the European Committee of Social Rights and by the supervisory mechanisms of the ILO.

\subsection{The Example of Spain}

During the 2017 financial crisis Spain faced severe pressure from the markets, which doubted Spain's creditworthiness, as well as from the EU, to implement structural measures to make the labour market more flexible and appealing to investors. ${ }^{11}$ As early as 2011, following the failure of negotiations between the social partners, the Socialist Government of Zapatero (PSOE) had adopted Royal Decree 7/2011, which for certain matters identified the company level as the priority level for collective bargaining, adjusting the procedure for refusing and renegotiating collective bargaining agreements. ${ }^{12}$ This reform was seen by the trade unions as a breach of their collective autonomy and led to partial decentralisation.

Later in 2011, the right-wing conservative government of Rajoy (Partido Popular) came to power. The Rajoy government proved much more inclined to make changes to the collective bargaining system. On 25 January 2012, the Spanish social partners concluded a national social agreement (the 'Segundo Acuerdo sobre Empleo y Negociación Colectiva' or 'II AENC') which would regulate the future rules and structures for collective bargaining in Spain. It also defended negotiations at national or central level as the main method. However, the government ignored this collective agreement and two weeks later adopted Royal Decree 3/2012 of 10 February $2012^{13}$ (later also Law

11 Council Recommendation of 12 July 2011 on the 2011 National Reform Programme 2011 of Spain and delivering a Council opinion on Spain's updated Stability Programme for 2011-2014 [2011] OJ C212/1, 1-4, recommendation 5, consid. 15; Borja Suárez Corujo, 'Crisis and Labour Market in Spain' (2014) 5(1) European Labour Law Journal 43, 47.

12 Real Decreto-ley 7/2011 de 10 de junio de medidas urgentes para la reforma de la negociación colectiva, $B O E$ no. 139, 11 June 2011; Suárez Corujo (n 11) 49.

13 Real Decreto-ley 3/2012 de 10 de febrero de medidas urgentes para la reforma del mercado laboral, BOE nr. 36, 11 februari 2012. 
3/2012 in parliament ${ }^{14}$ ), which revoked the agreements made in II AENC and radically reformed the rules of the collective bargaining system. ${ }^{15}$ The Rajoy government considered that reform was necessary because the current system limited the ability of employers to reorganise themselves without restricting employment. ${ }^{16}$ In other words, employers would only be able to survive the crisis if wages dropped.

The subsequent 2012 reform can be summarised in three main points. First, it provided for a kind of temporary opt-out, which would prevent the application of certain provisions of sectoral collective agreements at the company level. ${ }^{17}$ It also relaxed the conditions for derogating from collective agreements and extended the list of subjects to be covered by the derogation. Finally, it imposed a binding arbitration procedure, to be applied when the parties to collective bargaining do reach a solution within a certain period of time. At company level, the opt-out is clearly to the advantage of the employer, who sees his unilateral decision-making power strengthened in relation to the employees. Second, the reform prioritised the company level for collective bargaining over sectoral collective bargaining agreements. ${ }^{18}$ This is the case for labour conditions such as working time, work functions and the compensation system. This latter aspect of the reform has been, undoubtedly, an important form of decentralisation. Third, the reform fiddled with the extension mechanism as regards the duration of collective agreements. ${ }^{19}$

The ILO Committee on Freedom of Association took a rather negative view of the Spanish situation. ${ }^{20}$ First, it stated that the lack of involvement and consultation of the social partners in the adoption of the Royal Decree and Law 3/2012 ran counter to the ILO principles of consultation, based on ILO Recommendation No. 113. Second, the Committee argued that the introduction

14 Ley $3 / 2012$ de 6 de juli de medidas urgentes para la reforma del mercado laboral, $B O E$ nr. 162, 7 juli 2012.

15 Fernando Rocha, 'Crisis and Austerity Policies in Spain: Towards an Authoritarian Model of Industrial Relations' in Fernando Rocha (ed), The New EU Economic Governance and its Impact on the National Collective Bargaining Systems (Fundación $1^{\circ}$ de Mayo 2014) 187-9; Suárez Corujo (n 11) 50-1.

16 Spain (Ministry of Employment), Report evaluating the labour market reform, 2013, 5 .

17 Rocha (n 15) 188; Suárez Corujo (n 11) 56; Felice Testa, 'Employees' Participation in the Enterprise - Involvement and Collective Bargaining, Comparative Thoughts in Search for a Common European Denominator' (2013) 4 European Journal of Social Law 312, 330.

18 Rocha (n 15) 188; Suárez Corujo (n 11) 56; Testa (n 17) 330.

19 Rocha (n 15) 188; Suárez Corujo (n 11) 57; Testa (n 17) 330.

20 ILO CFA, 371st report, case no. 2947 (Spain), Complaint of 12 May 2012; M.

Luz Rodríguez, 'Labour Rights in Crisis in the Eurozone: the Spanish Case' (2014) 1

European Journal of Social Law 128, 136. 
of procedures that systematically give preference to decentralised negotiations - which ensure that priority is given to the provisions of higher-level collective agreements - could destabilise the collective bargaining system and employers' and workers' organisations. In this respect, freedom of association and collective bargaining would be weakened, contrary to the principles of ILO Conventions Nos 87 and 98. The serious nature of the economic crisis in Spain did not simply dispel these concerns. The Committee also drew attention to the strong opposition to the reform expressed by the social partners, in this case the trade unions, and stated that definition of the levels of the collective bargaining system should be left primarily to the social partners. Spain, together with the social partners, was called upon to review the 2012 reform and, henceforth, to consult the social partners in advance regarding similar reforms.

The European Committee on Social Rights (ECSR) was also critical of the 2012 reforms. In its Conclusions (XX-3) of 12 May 2014, it found that Spain did not comply with Article 6(2) ESC for two reasons. ${ }^{21}$ First, it follows the reasoning of the ILO's Committee on Freedom of Association in stating that the lack of consultation of the social partners when amending the rules for collective bargaining resulted in a failure to comply with the obligation to promote free negotiations under Article 6(2) ESC. It should be noted that no reference was made to Article 6(1) ESC. Second, the Committee considered that the possibility for the employer to unilaterally derogate, subject to certain conditions, from a freely concluded collective agreement constituted a breach of the obligation under Article 6(2) ESC. Unlike the ILO Committee, the ECSR did not see any disproportionate restriction of the right to collective bargaining in the forced decentralisation by making company level the primary bargaining level. According to the ECSR, this would be covered by the State's margin of appreciation.

The 2012 reform was an almost perfect follow-up to the EU CSR of 2011.22 Although this CSR had called for the reform to be implemented after consultation with the social partners, which the Spanish government had not involved, its call was otherwise met. In addition, the Spanish reforms had the support of the European Central Bank (ECB), the Organisation for Economic Co-operation and Development (OECD) and the International Monetary Fund (IMF). ${ }^{23}$ The pressure therefore did not come from EU economic governance only.

The European Commission praised the measures taken, and decentralisation, as the right way to increase employment through a less rigid system and

21 ECSR, Conclusions XX-3, Spain, Article 6(2) ESH.

22 Council Recommendation (n 11) 1-4, recommendation 5, consid. 15.

23 Rocha (n 15) 185; Rodríguez (n 20) 133-6. 
lower labour costs. ${ }^{24}$ The 2012 Recommendations no longer included a recommendation on wage setting, but in the Commission's considerations there was a call for the elaboration of the 2012 reform to be monitored. ${ }^{25}$ There was no reference to the lack of consultation with or agreement of the social partners, as called for by the 2011 Recommendations. In the considerations of the 2014 CSRs, the EU continued to be satisfied with the effects of the 2014 reform, yet a new Recommendation called on Spain to limit wage developments with the aim of promoting job creation. ${ }^{26}$ In the Staff Working Document of 2015, the Commission also stated that the 2012 reform had lowered labour costs and made the Spanish economy more competitive. ${ }^{27}$ However, in this document and in the CSRs of 2015 the Commission expressed concern about the new intersectoral agreement of the social partners for 2015-17, which envisaged wage increases - the Commission considered that wages in some companies and sectors should fall below productivity levels in order to remain competitive. ${ }^{28}$ It is clear that the Commission again opposed wage bargaining at higher levels, despite the 2012 reform. The fact that the Spanish Supreme Court had overturned the limitation of the one-year prolongation of collective agreements beyond their duration was also not welcomed by the EU. The 2015 Recommendations therefore contained a new incentive to bring wages in line with productivity. ${ }^{29}$ However, this recommendation did not return in 2016, 2017 and 2018.

\subsection{The EU at Odds with Other Legal Orders}

In previous research, which considered the example of Spain and the situation in other Member States, the painful conclusion was that the EU was actually

24 European Commission, In-Depth Review for Spain in accordance with Article 5 of Regulation (EU) No 1176/2011 on the prevention and correction of macroeconomic imbalances SWD(2013) 116, def., 33.

25 Council Recommendation of 10 July 2012 on the 2012 National Reform Programme of Spain and delivering a Council opinion on Spain's updated Stability Programme for 2012-2015 [2012] OJ C219/81, consid. 14.

26 Council Recommendation 8 July 2014 on the 2014 National Reform Programme of Spain and delivering a Council opinion on Spain's Stability Programme for 2014 [2014] OJ C247/35, consid. 13.

27 European Commission, 'Country Report Spain 2015 Including an In-Depth Review on the prevention and correction of macroeconomic imbalances' (2015) European Economy, Occasional Papers 216/June 2015, 42.

28 Council Recommendation 14 July 2015 on the 2015 National Reform Programme of Spain and delivering a Council opinion on Spain's Stability Programme for 2015 [2015] OJ C272/46, consid. 11; European Commission (n 27) 42.

29 Council Recommendation (n 28) 46-50, recommendation 3. 
using its EU economic governance system during the financial and economic crisis to push Member States to restrict the right to collective bargaining by taking particular measures. ${ }^{30}$ It was predominantly the most vulnerable Member States that were under enormous pressure from the financial markets due to their state debt or budgetary problems, or Member States that were saved by the EU, ECB and IMF, that did not see any other option but to follow the recommendations and demands of the EU and Troika.

It is questionable if, by pushing Member States into restricting certain social rights, the EU was respecting its own social principles laid down in the Treaties (such as Articles 151-3 TFEU) and the Charter of Fundamental Rights of the EU (CFREU). Calling on Member States to implement measures which allow companies to derogate from collective bargaining agreements does seem hard to reconcile with the objective in Article 151 TFEU to promote social dialogue between management and labour, and with the right to collective bargaining in Article 28 CFREU. At the same time, EU economic governance may create a situation where the affected Member States' obligations towards the EU conflict with their internal (constitutional) social rights and also with their social rights obligations laid down in other legally binding international treaties, such as the ILO Conventions, the ESC (revised or not) and even the European Convention on Human Rights. As suggested with the example of Spain, following EU recommendations can subject Member States to condemnation by supervisory mechanisms of other legal orders. These legal orders, which protect fundamental rights, hold a special position for the EU itself, as indicated in Article 151 TFEU which states that 'The Union and the Member States, having in mind fundamental social rights such as those set out in the European Social Charter signed at Turin on 18 October 1961 [...] shall have as objective [...]'. Also, the CFREU expressly states that its provisions cannot be interpreted differently than the provisions of the European Convention of Human Rights. ${ }^{31}$ In addition, the EU has made significant efforts to become a party to the European Convention of Human Rights (so far blocked by the CJEU).$^{32}$ In light of this it is clear that there is a problem of legal incoherence,

30 Pecinovsky (n 3) 323-443; Pieter Pecinovsky, 'Economic Governance and the Right to Collective Bargaining. Part 2. From Imposed Restrictions of the Right by EU Member States Towards a Social Economic Governance' (2019) 10 European Labour Law Journal 43.

31 Article 52(3) CFREU; Jean-Paul Jacqué, 'The Charter of Fundamental Rights and the Court of Justice of the European Union: A First Assessment of the Interpretation of the Charters' Horizontal Provisions' in Lucia Serena Rossi and Federico Casolari (eds), The EU after Lisbon (Springer 2014) 157-9.

32 Paul Craig, 'EU Accession to the ECHR: Competence, Procedure and Substance' (2013) 36 Fordham International Law Journal 1114, 1131; Christina Eckes, 'EU Accession to the ECHR: Between Autonomy and Adaptation' (2013) 76(2) The 
which not only diminishes the legal certainty for all actors involved, but also severely damages the social ambitions and dimension of the EU. ${ }^{33}$

\section{THE JUNCKER ERA}

\subsection{Renewed Focus on Social Europe}

Most of the restrictions of the right to collective bargaining which followed from EU economic governance, like the ones discussed above, took place during the Commission presidency of José Manuel Barroso, who had a rather neo-liberal reputation and did not undertake significant action to safeguard social rights. ${ }^{34}$ However, under the Commission presidency of Jean-Claude Juncker (2015-19) and Commissioner Marianne Thyssen (Employment, Social Affairs, Skills and Labour Mobility), the situation improved considerably. Not only was the crisis close to its end and the economies of the majority of the EU Member States back on track, but the Commission had also refocused its efforts on the EU's social dimension, with a renewed interest in European social dialogue ${ }^{35}$ and an ambitious social programme, including the European Pillar of Social Rights (2017). ${ }^{36}$ This so-called Social Pillar includes

Modern Law Review 254, 263-5 and 278-9; Tobias Lock, 'End of an Epic? The Draft Agreement on the EU's Accession to the ECHR' (2012) 31(1) Yearbook of European Law 162, 162; Jed Odermatt, 'The EU's Accession to the European Convention on Human Rights: An International Law Perspective' (2014) 47(1) New York University Journal of International Law and Politics 59, 70-81; Editorial comments, 'The EU's Accession to the ECHR - a "NO" from the ECJ!' (2015) 52(1) Common Market Law Review 1, 2.

33 Hendrickx and Pecinovsky (n 1) 147-9.

34 Erne (n 4) 345-68.

35 Statement of the Presidency of the Council of the European Union, the European Commission and the European Social Partners, 'A new start for social dialogue', 27 June 2016, 4; European Commission, A new start for social dialogue (Publications Office of the European Union 2016) 11; European Commission, European Social Dialogue, E-newsletter, 28 juni 2016, no. 2.

36 European Commission, 'Social summit for fair jobs and growth: strengthening the social dimension of Europe', press release, 16 November 2017, IP/17/4643; European Parliament, Council of the European Union and European Commission, European Pillar of Social Rights, (Publications Office of the European Union 2017) 23; European Council, Conclusions of 14 December 2017, Brussels, http://data.consilium .europa.eu/doc/document/ST-19-2017-REV-1/en/pdf, accessed 20 June 2021; European Commission, Establishing a European Pillar of Social Rights, SWD(2017) 201 final; Simon Deakin, 'What Follows Austerity? From Social Pillar to New Deal' in Frank Vandenbroucke, Catherine Barnard and Geert De Barere (eds), A European Social Union after the Crisis (CUP 2017) 160-91; Klaus Lörcher and Isabelle Schömann, The European Pillar of Social Rights: Critical Legal Analysis and Proposals (ETUI 2016) 
a principle of social dialogue (including respect for the right to collective bargaining and the autonomy of the social partners). ${ }^{37}$ On one hand, the legal status of the Pillar is vague and certainly not binding for the Member States. On the other, this EU Commission was determined to uphold the principles listed in the Pillar and to expressly apply them on the European Semester. ${ }^{38}$ Furthermore, the Social Pillar included a social scoreboard in the European Semester - which, however, does not look at social dialogue or collective bargaining. ${ }^{39}$

In addition, it is worth noting that, since 2015, there has been a remarkable decline in the number of Recommendations from the Member States calling for measures that restrict the right to collective bargaining. Yet, since the 'Five Presidents Report' of the same year, ${ }^{40}$ the general amount of CSRs has dropped and the content has become less specific, thus leaving a broader margin of appreciation for the Member States. ${ }^{41}$ In 2014 the Member States still received a total of 157 Recommendations and 74 social Recommendations; this decreased to 73 Recommendations in total and 46 social Recommendations in 2019..$^{42}$ In 2017, the EU continued to ask certain Member States to intervene in wage setting and Italy was still recommended to decentralise. ${ }^{43}$ In contrast, some countries were also urged by the EU to strengthen social dialogue (see

119; Zane Rasnača, 'Bridging the Gaps or Falling Short? The European Pillar of Social Rights and What It Can Bring to EU-Level Policymaking' (2017) ETUI working paper 2017.5, 44

37 Eighth principle of European Pillar of Social Rights.

38 European Commission, Concluding report Social Summit for Fair Jobs and Growth, 2 and 5, 17 November 2017 https:/ec.europa.eu/info/sites/default/files/ concluding-report-social-summit_en.pdf, accessed 20 June 2021.

39 European Commission, Working Document 'The Social Scoreboard' with 'the establishment of a European Pillar of Social Rights' SWD(2017) 200 final.

40 European Commission, 'The Five Presidents' Report: Completing Europe's Economic and Monetary Union', 2015, https://wayback.archive-it.org/12090/ 20191231140925/https://ec.europa.eu/commission/sites/beta-political/files/5 -presidents-report_en.pdf, accessed 20 June 2021; see also European Commission, On steps towards Completing Economic and Monetary Union COM(2015) 600 final.

${ }_{41}$ See also the systematic overview of the change in the number of social recommendations in Stefan Clauwert, 'The country-specific recommendations (CSRs) in the social field an overview and comparison Update including the CSRs 2019-2020' (2019) ETUI Background analysis 2019.03, 11.

42 The social recommendations have more or less gained importance. In 2014 the social recommendations accounted for just 47 per cent of the recommendations, but this climbed to 63 per cent in 2019.

43 Stefan Clauwert, 'The country-specific recommendations (CSRs) in the social field. An overview and comparison. Update including the CSRs 2017-2018' (2017) ETUI Background Analysis 2017.02, 14. 
the example of Romania in 2018). ${ }^{44}$ This shows that the issue of EU economic governance restricting the right to collective bargaining did not disappear, but the number of incidences dropped steadily and the CSRs were suddenly also used to promote social dialogue and collective bargaining. In order to better understand the transformation to a more social EU economic governance under the Juncker Commission, in the following section the CSRs of 2018 and 2019 will be discussed.

\subsection{Recommendations under the Juncker Commission}

First, it is important to observe that in 2018, for the first time ever, there was not a single Recommendation on the decentralisation of collective bargaining. No such Recommendation could be identified in 2019, either. It is possible that academics' and social partners' criticism of this type of recommendation has helped to vanquish support for such measures, effectively withdrawing the issue from debate. In addition, the IMF and the OECD have, in recent years, also tempered their enthusiasm for the supposed economic benefits of decentralisation measures. ${ }^{45}$ Still, Recommendations on social policy and employment, including wages, were plentiful. Nonetheless, these Recommendations do not seem to have implied the same interventionist strategy as was seen during the crisis, and they often include a positive discourse in favour of social dialogue and wage increases.

In 2018, Croatia was asked to introduce harmonised wage-setting frameworks across the public administration and public services, in consultation with the social partners, because the lack of coherence in the wage-setting frameworks in the public sector impeded equality of treatment and government control over the public wage bill. ${ }^{46}$ The same recommendation was repeated in 2019 as new legislation was postponed by Croatia. ${ }^{47}$ The new law should achieve greater harmonisation through the introduction of common wage grids and job complexity coefficients, based on more consistent job descriptions and

44 Ibid, 109.

45 Olivier Blanchard, Florence Jaumotte and Prakash Loungani, 'Labor Market Policies and IMF Advice in Advanced Economies during the Great Recession' (2014) 3(2) IZA Journal of Labor Policy 1, 8-9; IMF, World Economic Outlook: Too Slow for Too Long (IMF 2016) 131-2; OECD, Employment Outlook 2017 (OECD Publishing 2017) 128.

46 Council Recommendation 13 July 2018 on the National Reform Programme 2018 of Croatia and delivering a Council opinion on the 2018 Convergence Programme of Croatia [2018] OJ C320/44, recommendation 3, consid. 12.

47 Council Recommendation 9 July 2019 on the National Reform Programme 2019 of Croatia and delivering a Council opinion on the 2019 Convergence Programme of Croatia [2019] OJ C301/64, recommendation 2, consid. 9. 
competence frameworks. The social partners should have an important say on this. However, the Croatian social partners expressed concern that the working methods and procedures proposed by the Croatian government would hinder real social dialogue. The fragmentation of trade unions makes social dialogue less effective than it should be. ${ }^{48}$ Therefore, the recommendation can be seen as enhancing the involvement of social partners and promoting social dialogue in the public sector.

In the same year, the EU recommended that France ensured that minimum wage developments were consistent with job creation and competitiveness. Also, the considerations of the CSR make clear that there could be a problem with the indexation of the minimum wage. ${ }^{49}$ Yet the French national minimum wage is not set by the social partners - which, in addition, can derogate in favour of workers, by laying down higher minimum wages in collective agreements. Therefore, this Recommendation is not necessarily problematic in light of the right to collective bargaining. In contrast, Germany and the Netherlands received recommendations to promote higher wage growth, while respecting the role of the social partners (urging wage increases).$^{50}$ Both countries had seen only moderate nominal wage increases, despite low unemployment and high job vacancy rates. Germany had introduced a minimum wage in 2015 (also following a recommendation of the EU) which boosted lower wages; however, its share of low-paid workers, at 22.5 per cent in 2017, remains considerably above the average in the EU. Further wage growth would support domestic demand and contribute to euro-area rebalancing (as the lower wages in Germany are seen as unfair competition to other Member States). In any case, these recommendations paint a completely different picture compared to other Member States, which, during the crisis, were presented with recommendations to reduce their wage growth. In addition, the EU asked Romania

48 Ibid, recommendation 2, consid. 9; Clauwert (n 41) 28.

49 Council Recommendation 13 July 2018 on the National Reform Programme 2018 of France and delivering a Council opinion the 2018 Stability Programme of France [2018] OJ C320/39, recommendation 2, consid. 14.

50 Council Recommendation 13 July 2018 on the National Reform Programme 2018 of Germany and delivering a Council opinion the 2018 Stability Programme of Germany [2018] OJ C320/60, recommendation 2, consid. 14; Council Recommendation 9 July 2019 on the National Reform Programme 2019 of Germany and delivering a Council opinion the 2019 Stability Programme of Germany [2019] OJ C301/48, recommendation 2, consid. 18; Council Recommendation 13 July 2018 on the National Reform Programme 2018 of the Netherlands and delivering a Council opinion the 2018 Stability Programme of the Netherlands [2018] OJ C320/80, recommendation 2, consid. 14 and recommendation 1, consid. 11. 
to improve the functioning of social dialogue. ${ }^{51}$ The involvement of social partners in the design and implementation of economic and social reforms has been very limited. The views of social partners are frequently not taken into account, even when they converge. According to the EU in 2018:

Romania's collective bargaining framework is not conducive to a well-functioning system of industrial relations. Social dialogue is characterised by a low level of collective bargaining, especially at sectoral level and low membership of trade unions and employers' organisations. High representativeness thresholds and the vague definition of sectors are among the key obstacles to more effective social dialogue. Legislative amendments to improve the framework have progressed little so far. ${ }^{52}$

Further, in 2019, the consideration states:

Social dialogue is characterised by low collective agreement coverage, in particular at sectoral level, also due to the current definition of sectors. The authorities have initiated plans to revise the definitions of economic sectors but no agreement has yet been reached. Beyond the collective bargaining framework, the timely and meaningful involvement of social partners on policy issues and reforms is limited. Most social dialogue takes place formally, within the Economic and Social Council and the Social Dialogue Committees. However, despite the established framework of dialogue and consultations, the stability and the role of these institutions has weakened over the last year. ${ }^{53}$

By pushing Romania to act and by following up on the measures previously implemented, the EU can be seen as taking its role as guarantor of social dialogue seriously, in line with Articles 151 and 152 TFEU and the Social Pillar. Besides recommendations on collective bargaining, other noteworthy social recommendations were extended to the Member States. ${ }^{54}$ These are mainly concerned with the inclusion of younger, older, female, lower-skilled and migrant workers into the labour market, the improvement of education and skills to pair with a changing labour market and the safeguarding of the sustainability of the pension system. This last category could be problematic, as it could be interpreted as a recommendation to increase the retirement age, as was often the case. However, in recent years the EU has started to include

51 Council Recommendation 13 July 2018 on the National Reform Programme 2018 of Romania and delivering a Council opinion on the 2018 Convergence Programme of Romania [2018] OJ C320/98, recommendation 3, consid. 13.

52 ibid, consid. 13.

53 Council Recommendation 9 July 2019 on the National Reform Programme 2019 of Romania and delivering a Council opinion on the 2019 Convergence Programme of Romania [2019] OJ C301/135, consid. 16.

54 All mentioned recommendations below can be found back in the 2019 Country Specific Recommendations. 
the warning that pensions need to remain adequate. Member States such as Spain and Portugal have been warned that the social safety net (social protection systems) should be improved. ${ }^{55}$ Germany, Austria and Poland were urged to work on the transition towards more permanent and full-time employment (instead of precarious part-time and temporary jobs). ${ }^{56}$ Equally, Italy, Austria and the Czech Republic were asked to increase employment among women, for example by providing cheaper childcare services, ${ }^{57}$ and Estonia was asked to work on closing its pay gap between men and women. ${ }^{58}$

\section{THE VON DER LEYEN COMMISSION}

As will be shown below, the Commission under the presidency of Ursula von der Leyen seems to have sought to continue the so-called Juncker transformation discussed above. Von der Leyen picked Luxembourger Nicolas Schmit as Commissioner for Jobs. Looking at his background (ex-Minister of Employment, ex-chairman of the EPSCO network of the Party of European Socialists, ex-member of the Committee on Employment and Social Affairs in the EP), he appears to have the right experience to assume this position.

It is worth mentioning that the title of the Commissioner's competence has changed since Marianne Thyssen's time: from 'Employment, Social Affairs, Skills and Labour Mobility' into, simply, 'Jobs'. Moreover, the separate

55 Council Recommendation 9 July 2019 on the National Reform Programme 2019 of Spain and delivering a Council opinion on the 2019 Stability Programme of Spain [2019] OJ C301/48, recommendation 2; Council Recommendation 9 July 2019 on the National Reform Programme 2019 of Portugal and delivering a Council opinion on the 2019 Stability Programme of Portugal [2019] OJ C301/55, recommendation 2.

56 Council Recommendation 9 July 2019 on the National Reform Programme 2019 of Germany (n 50) recommendation 2; Council Recommendation 9 July 2019 on the National Reform Programme 2019 of Austria and delivering a Council opinion on the 2019 Stability Programme of Austria [2019] OJ C301/117, recommendation 2; Council Recommendation 9 July 2019 on the National Reform Programme 2019 of Poland and delivering a Council opinion on the 2019 Convergence Programme of Poland [2019] OJ C301/123, recommendation 2.

57 Council Recommendation 9 July 2019 on the National Reform Programme 2019 of Italy and delivering a Council opinion on the 2019 Stability Programme of Italy [2019] OJ C301/69, recommendation 2; Council Recommendation 9 July 2019 on the National Reform Programme 2019 of Austria (n 56) recommendation 2; Council Recommendation 9 July 2019 on the National Reform Programme 2019 of the Czechia and delivering a Council opinion on the 2019 Convergence Programme of the Czechia [2019] OJ C301/15, recommendation 2.

58 Council Recommendation 9 July 2019 on the National Reform Programme 2019 of Estonia and delivering a Council opinion on the 2019 Stability Programme of Estonia [2019] OJ C301/30, recommendation 2. 
Commissioner competence for social dialogue, which belonged to Valdis Dombrovskis, has been removed, although Dombrovskis himself was promoted to Vice-President of the Commission and received the competence 'an economy that works for the people'. In her mission letter, von der Leyen made it clear that this means that social rights, protection and fairness should be put at the heart of the EU's modern economy. ${ }^{59}$ She asked Dombrovskis to coordinate the work on the action plan to implement the European Pillar of Social Rights. In particular, she suggested prioritising the relationship with the social partners and leading the work on strengthening the role of social dialogue at European level, essentially retaining the old competence of social dialogue.

Even more interestingly, von der Leyen's mission letter to Schmit made it clear that the Commission intends to develop an action plan to implement the Social Pillar, which underlines the fact that it intends to follow the path of the Juncker Commission. Further, the Commission required a legal instrument to ensure that every worker in the Union receives a fair minimum wage; to closely monitor and enforce existing EU legislation regarding dignified, transparent and predictable working conditions; to look at ways to improve the labour conditions of platform workers; to promote social dialogue and engage with social partners at the EU level across all priorities; and to work closely with Member States to strengthen social protection systems in Europe, notably by using the European Semester to monitor progress and identify areas for improvement. ${ }^{60}$

At his confirmation hearing, Schmit stated that

social dialogue can only work when built on strong, autonomous national social partners. Likewise, collective bargaining should also be supported, as it constitutes an important feature of our social market economy. As Commissioner, I will fully engage in a dialogue, both with the European Parliament and the Council, but also with national parliaments and national social partners. ${ }^{61}$

59 Ursula von der Leyen, Mission letter to Valdis Dombrovskis, Brussels, 10 September 2019, https://multimedia.europarl.europa.eu/documents/20143/0/mission -letter-valdis-dombrovskis-2019_en+\%281\%29.pdf/d3645133-8c2e-7fdd-4367 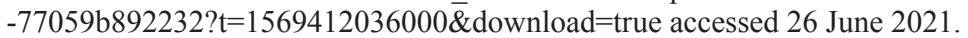

60 Ursula von der Leyen, Mission letter to Nicolas Schmit, Brussels, 10 September 2019, https://ec.europa.eu/info/sites/default/files/mission-letter-nicolas-schmit_en.pdf accessed 26 June 2021.

${ }_{61}$ European Commission, 'Reinforcing the social dimension', Social Agenda November 2019, 9 . 
In particular, his appreciation for the concept of 'social economy' indicates a willingness to end the primacy of the economic dimension over the social dimension of the EU. ${ }^{62}$

In light of the above, it is evident that the von der Leyen Commission intends not only to introduce new social legislation, but also to monitor the implementation of existing legislation with the help of the EU economic governance mechanism. In January 2020, the Commission released a Communication in which it presented a roadmap with preparations for installing the action plan on the implementation of the Social Pillar in $2021 .{ }^{63}$ The Communication seeks the active engagement and participation of all the stakeholders, including the social partners, in providing contributions and ideas, which will be gathered and analysed for the purposes of the action plan itself. The action plan was published at the beginning of 2021 and adopted by the Member States at the Social Summit of Porto in the Porto Declaration of 8 May 2021. ${ }^{64}$ The action plan makes it clear that the European Semester will continue to play an important role in the coordination and guidance of the national social policies in order to implement the principles of the Social Pillar and to reach the targets of the Action Plan.

\section{THE CORONAVIRUS CRISIS: THE END OF THE ESM AS WE KNOW IT?}

As this contribution is being finalised in the midst of the COVID-19 pandemic, it is impossible not to mention the latest turn of events with regard to the ESM without touching on matters not yet known. The Commission, the ECB and the Council have taken a list of measures in order to support the Member States following the outbreak of the pandemic. Among others, the Commission promised to be flexible when monitoring budgetary deficits in the European Semester. Further, in order to financially support Member States of the EU and especially the eurozone, the Eurogroup reached an agreement on Thursday 9 April 2020 to activate ESM funds reaching 540 billion euros. $^{65}$

${ }^{62}$ European Commission, 'Reinforcing the social dimension', Social Agenda November 2019, 7.

63 European Commission, 'A Strong Social Europe for Just Transitions' COM(2020) 14 final.

64 European Commission, The European Pillar of Social Rights Action Plan' (Publications Office of the European Union 2021) 48; European Council, 'The Porto Declaration' 8 May 2021, Press Release, www.consilium.europa.eu/en/press/press -releases/2021/05/08/the-porto-declaration/, accessed 20 June 2021.

65 Eurogroup, 'Report on the comprehensive economic policy response to the COVID-19 pandemic', Press release, 9 April 2020, www.consilium.europa.eu/en/press/ 
At first glance, it seems only normal that the ESM would be utilised in a crisis of this magnitude. However, Italy and Spain, being the main (initial) victims of the pandemic, have not forgotten the dark side of the ESM, which surfaced during the economic and financial crisis. This is why they urged the other Member States to liberate the ESM funds without the usual conditions of restructuring and austerity. After long negotiations in the Eurogroup and thanks to strong opposition from some countries, including the Netherlands, Austria, Denmark and Sweden, the Member States agreed to drop the usual conditions and the much-feared Troika monitoring procedure. This would mean that the ESM Treaty would have to be adjusted.

On 27 May 2020 the Commission proposed a new recovery plan, which did not mention the ESM at all but explored the possibility for the EU to loan 750 billion euros to the financial markets, which the Member States will be able to invest according to the priorities laid down in the European Semester. ${ }^{66}$ At the extraordinary summit of 17-21 July 2020, the Member States reached a hard-fought agreement in the council on the EU budget for 2021-7 and the recovery plan. ${ }^{67}$ The recovery plan, titled 'NextGenerationEU', includes the 750 billion euros which the Commission had proposed. This amount, however, is divided into loans of 360 billion euros, which the Member States will have to pay back, and 390 billion euros in subsidies, which will not have to be paid back. This division makes it clear that the deal is a compromise between budgetarily strict Member States such as the Netherlands, which did not want financial support to come from subsidies, on the one hand, and Member States that did not want it to include loans, mostly Spain and Italy, on the other. The deals do not include any veto rights on the awarding of the financial support, but Member States will have to submit national plans for recovery and economic reforms. It is safe to conclude that EU economic governance will play an important role in these post-coronavirus plans.

In addition, the focus of the Commission's proposals for CSRs in 2020 is clearly COVID-related (including such matters as investment in health care and economic recovery). Most interestingly, the Commission has activated the general escape clause of the Stability and Growth Pact due to the major

press-releases/2020/04/09/report-on-the-comprehensive-economic-policy-response-to -the-covid-19-pandemic/, accessed 20 June 2021.

${ }^{66}$ European Commission, Europe's moment: Repair and Prepare for the Next Generation $\operatorname{COM}(2020) 456$ final.

67 European Council, Conclusions of the Special meeting of the European Council (17, 18, 19, 20 and 21 July 2020), EUCO 10/20, https://data.consilium.europa.eu/doc/ document/ST-10-2020-INIT/en/pdf, accessed 20 June 2021. 
economic crisis caused by the COVID-19 pandemic. ${ }^{68}$ This allows the EU Member States to discard the budgetary rules of the SGP in order to take the measures necessary to cope with the crisis. Therefore, the Member States did not receive any budgetary recommendations in the CSR 2021. ${ }^{69}$ Another interesting evolution is the fact that social dialogue has clearly become a central issue in the CSR 2020, with as many as 15 EU Member States receiving recommendations in order to promote social dialogue. ${ }^{70}$ This significant increase can also be linked to the intention to use the European Semester to implement the Social Pillar, which promotes social dialogue in its eighth principle.

\section{CONCLUSIONS}

In the past, EU economic governance has repeatedly put pressure on Member States to restrict the right to collective bargaining and, possibly, other fundamental social rights. In certain cases, and especially when pressure from the EU increased, these restrictive measures were far-reaching and difficult to justify. Even under the Juncker Commission, the threat posed by EU economic governance to the right to collective bargaining was not completely eliminated. Moreover, there is no clear legal mechanism to prevent a new economic crisis from leading to fresh restrictive recommendations and measures, especially in view of the current COVID-19 pandemic. Hopefully, EU institutions will remember the lessons learned from the shortcomings of EU economic governance in the recent past. The pandemic is expected to put the social dimension of the EU to the test and make its reinforcement and implementation a priority.

Since 2015 we have seen a positive evolution towards less damaging social recommendations, and from 2018 the CSRs have been expected to take into account the principles of the European Pillar of Social Rights. In the 2018 and 2019 European Semester, recommendations that constitute a clear danger of imposing measures which would severely restrict the right to collective bargaining remained absent. In contrast, it seems that EU economic governance

68 European Commission, Communication from the Commission to the Council on the activation of the general escape clause of the Stability and Growth Pact COM (2020) 123 final; Silvia Rainone, 'An overview of the 2020-2021 country-specific recommendations (CSRs) in the social field. The impact of Covid-19' (2020) ETUI Background Analysis 2020.1, 8 .

69 European Commission, '2020 European Semester: Country Specific Recommendations/Commission Recommendations', https:/ec.europa.eu/info/ publications/2020-european-semester-country-specific-recommendations-commission -recommendations en, accessed 20 June 2021.

70 Rainone (n $\overline{68}$ ) 15. 
is gradually being used as a tool to promote social dialogue and to strengthen the role of social partners and collective bargaining in the EU Member States.

The EU, under the social ambitions of the Juncker Commission, took important steps to correct the damage that EU economic governance has done to the right to collective bargaining in EU Member States. With the further implementation of the Social Pillar and the current Commission's continuing interest in the social dimension of the EU, it will be interesting to see whether EU economic governance can reinforce the social dimension. It remains to be seen whether the EU institutions can overcome the limits of their restricted legal competences in the field of social policy when taking up the role of guardians of fundamental social rights in Europe.

In the face of a new economic and social crisis caused by the pandemic, the Eurogroup's agreement to engage the ESM funds without its usual conditions of austerity was another hopeful sign that the EU and its Member States have learned their lesson and will not return to the economic governance of the past. Also, the activation of the escape clause of the SGP and recovery plan give very different signals from the austerity-driven economic governance of the EU during the previous crisis. However, there are still certain challenges to be addressed, reflected in the difficulty of reaching agreement due to certain Member States' opposition to the ESM agreement and to the recovery plan of the Commission. This shows how fragile the social dimension of the EU and the solidarity between the Member States still is, and how easily EU governance may return to its bad habits. The coming years will tell if the von der Leyen Commission, together with other EU institutions, can achieve the necessary unity and solidarity among all of the EU Member States to overcome the threat of this new crisis. 